\title{
West African Migrations to Italy: An Anthropological Analysis of Ghanaian and Senegalese Politics of Mobility in Emilia Romagna
}

Migrations ouest-africaines vers l'Italie : une analyse anthropologique des politiques de mobilités ghanéennes et sénégalaises en Émilie-Romagne Las migraciones de África Occidental a Italia: un análisis antropológico de las políticas de movilidad desde Ghana y Senegal en Emilia Romagna

Selenia Marabello and Bruno Riccio

\section{(2) OpenEdition}

\section{Journals}

Electronic version

URL: http://journals.openedition.org/remi/10193

DOI: $10.4000 /$ remi. 10193

ISSN: $1777-5418$

\section{Publisher}

Université de Poitiers

\section{Printed version}

Date of publication: 1 April 2018

Number of pages: 127-149

ISBN: 979-10-90426-61-0

ISSN: 0765-0752

\section{Electronic reference}

Selenia Marabello and Bruno Riccio, « West African Migrations to Italy: An Anthropological Analysis of Ghanaian and Senegalese Politics of Mobility in Emilia Romagna », Revue européenne des migrations internationales [Online], vol. 34 - $n^{\circ} 1$ | 2018, Online since 28 December 2019, connection on 04 January 2021. URL : http://journals.openedition.org/remi/10193; DOI : https://doi.org/10.4000/remi.10193 


\title{
West African Migrations to Italy: An Anthropological Analysis of Ghanaian and Senegalese Politics of Mobility in Emilia Romagna
}

\author{
Selenia Marabello and Bruno Riccio²
}

\begin{abstract}
Contemporary African migration is characterised by a mobility paradox: thanks to the media and access to communication and transportation technologies, people are exposed to visions of the "good life" elsewhere but, with growing inequality and restrictive mobility regimes, they are excluded from the circuits of legal mobility (Kleist, 2017). In this article we apply a mobility perspective to reframe unequal power relations by emphasising expectations, obstacles and mobility practices in contexts of uncertainty and precariousness. This approach also helps us to observe mobility practices across the borders of states, emergent domestic economies and political institutions (Augé, 2012).
\end{abstract}

To test the heuristic value of such an approach, we explore how mobility-informed ethnographic and biographical accounts shed light on the changing political and economic landscape of Italy as a context of migration. By linking the theoretical debate on the "mobility turn" to empirical research findings, we illustrate how this approach challenges traditional analytical distinctions between internal vs transnational migration, settlers $v s$ temporary migrants, and labour vs forced migrants. We also present Senegalese and Ghanaian migrants' experiences with and narratives of mobility along and across internal Italian and European borders as well as their engagement with legal citizenship in order to show how contemporary mobility practices become devices for navigating not only uncertainty and unexpected precariousness but also migrants' horizons of expectation as well as cross-generational relations and visions of the future. Although this discussion is based on long-term research by both authors on Senegalese migration and the Ghanaian diaspora, the empirical material has been selected from ethnographic accounts produced between 2013 and 2015 as part of the shared research project Boundless mobility. Internal migrations and

\footnotetext{
1 Postdoc Fellow and Lecturer in Cultural Anthropology, University of Bologna, Department of Education Studies “G. M. Bertin", Filippo Re 6, 40126 Bologna, Italy; selenia.marabello@unibo.it

2 Professor of Cultural Anthropology and Migration Processes, University of Bologna, Department of Education Studies "G. M. Bertin", Filippo Re 6, 40126 Bologna, Italy; bruno.riccio@unibo.it
} 
social dynamics in Europe. ${ }^{3}$ Schematically, this article first provides a historical background of Senegalese and Ghanaian migration to Italy, and Emilia Romagna in particular, from the end of the 1980s to the present. We then theoretically engage with the mobility paradigm and its impact on the socio-anthropological study of migration through the lens of a biographical approach. Biographical trajectories shed light on the interplay between migrants' life strategies and shifting normative and economic structures. To begin, let us see how these structures developed.

\section{Historical Background}

During the last quarter of the twentieth century, following a national economic boom and political transformations throughout Europe, Italians began to realise that Italy was no longer a country of emigrants (as it had been for more than a century) (Grillo and Pratt, 2002). It was progressively becoming a destination for migrants from countries all over the world, attracted by a high demand for medium and low-skilled labour and limited migration legislation at the national level (Ambrosini, 2018). In the 1990s, of a total population of 58 million, there were more than one million migrants living in Italy, the majority having remained after their visas had expired. Certain factors played a key role in driving Italy to become one of the main destinations of Senegalese and Ghanaian immigration, with the most important being the lack of clear or comprehensive legislative framework on migration and the ease of obtaining a visa. Nonetheless, this state of affairs was subsequently reshaped by Italian economic restructuring after the 1970s, rising remuneration levels for Italian jobs and the growing segmentation of the Italian labour market, which led to a progressive decrease in direct competition between native workers and migrants (Pugliese, 2006). The history of West African emigration to Italy can be broken down into four different stages of settlement that highlight the relationship between processes of implementing more restrictive migration laws and migrants' decisions to reside for a longer period.

The first two phases (1981-1986 and 1987-1989) were closely linked to the implementation of the two laws issued in 1986 and 1989 aimed at regularizing the status of migrants. The two amnesty measures or sanatoria covered only regularly employed migrants, and their main outcome was to establish legal equality between Italian and foreign labourers. During this first decade, although Sicily, Sardinia, and Rome emerged as the favoured destinations, the two sanatoria triggered an extensive process of internal mobility in which many migrants moved from Italy's South to the North to pursue jobs in factories and craft industries more generally.

During the 1990s, in the third phase of West African migration, Italy's participation in the Schengen treaty and development of the first comprehensive national migration law (Martelli law) caused a radical change in the dynamics of migration. The Martelli law was aimed at correcting the previous law and

3 The research project, coordinated by one of the authors (Bruno Riccio), was founded by Alma Mater Studiorum University of Bologna's Farb Project and partially co-funded by the Bologna Municipality, Community's Wellbeing Department. 
made it mandatory for migrants to request legal residence rights (permesso di soggiorno). Moreover, the new law was no longer limited to labour migrants with employment contracts but rather covered all immigrants. Despite the obligation to secure a permesso di soggiorno, these legal measures extended labour rights and granted equal standing not only to employed labour migrants but to all people employed as street vendors. Between 1992 and 1998, these transformations attracted a growing number of West African migrants to the country.

From the end of the 1990s to the present, the fourth stage, two legal measures have been put in place: the Turco-Napolitano law n. 40 (1998) passed under the left-centre government of Romano Prodi and the Bossi-Fini law n. 189 (2002) passed under the right-centre government of Silvio Berlusconi. Although the tenets of these two laws stem from opposing political backgrounds and they involve different mechanisms of regularization, both adopt the directives of the Schengen agreement by making entry policies more restrictive. More specifically, the new "integration" tools promoted by the Turco-Napolitano law made it mandatory for immigrants to hold a residence card (carta di soggiorno) and created "Centres of Temporary Permanence" (CTP). The Bossi-Fini law entailed several measures to guarantee the "effective" (albeit selective) management of migration flows, the most prominent of which require migrants to secure an employment contract in order to enter the country and set annual fixed quotas on admission (Colombo, 2012). With the economic crisis, further social transformations have also occurred in the wake of more restrictive legal interpretations regulating temporary return and legal residence rights (permesso di soggiorno). These changes have also contributed to a significant shift in the organization and articulation of Senegalese and Ghanaian migratory routes. Some factors such as gender, level of education, destination area or nationality of origin have also affected migrants' access to Italian labour markets and local territories.

These phenomena can also be examined from the context of origin. It is important to note that Ghana has a long history of migration, both voluntary and forced, intra- and international, and directed at multiple countries. From the mid-1960s to the 1980s, the country's political instability drove many Ghanaians, especially the children of elites or highly-educated individuals, to migrate to the United States, Canada, and various European countries; many other skilled and unskilled Ghanaians instead relocated to Nigeria, from where they were expelled between 1983 and 1985. Taking into consideration the increasing number of Ghanaian migrants as well as their constellation of migration goals, Van Hear (1998) defined the 1980s and 1990s as the period of Ghanaian diasporisation. Southern Europe became a new destination, and substantial numbers of Ghanaian migrants arrived in Italy during this period. In the early stages, these migrants came mostly from urban centres and held a high school or university degrees (Manuh, 2006). In the later stages, especially from the late 1990s onward, they came mainly from rural areas, lacked formal education (Riccio, 2008) and tended to be younger in age, as a consequence of family reunification.

Senegalese emigration to Europe began in the colonial period, with France's recruitment of Tirailleurs at the end of the $19^{\text {th }}$ century and during World War I. After French West Africa gained independence (1962) migration levels rose, largely due to the French economic boom of the 1950s and 1960s and resulting demand for unskilled foreign labour. This emigration involved mainly Toucouleur 
(Fulani), Serere and, above all, "willing" Soninké migrants (Manchuelle, 1997; Timera, 1996). In the mid-1980s, however, the downsizing and restructuring of industrial enterprises in France had a marked affect on Senegalese workers. A new type of migration developed at that point, characterized by family or individual initiatives and a broader range of destinations, with access to trade playing a crucial role in the success of migratory strategies. Throughout the 1990s and early 2000s, young Senegalese people from the Baol (Touba, Diourbel), Djambour (Louga), Cayor (Kebemer), Sine (Kaolack) and Dakar left for new receiving countries such as Italy, Spain, and the United States. Through their circulatory movements, they shaped new transnational spaces (Riccio, 2008; Kane, 2011; Hernández-Carretero, 2016).

Most Ghanaians and Senegalese settled in northern Italy. In the majority of cases, time spent in southern Italy was only one stage in a larger migratory project. Indeed, legislative measures legalizing migrants and providing greater opportunities for employment in central and northern Italy drove migrants to move across regional borders, with Emilia Romagna representing one of the most common destinations. They were attracted to this region because of its inclusionary social policies and economic framework characterised by the success of highly specialised small and medium-sized enterprises that favour migrants' entry into local labour markets via jobs that might be precarious but are at least legal. The two sanatoria also granted impetus to this shift. Thanks to the employment opportunities offered by the region's industrial and manufacturing sectors, many foreigners were able to begin the process of "regularizing" their legal status (see Schuster, 2005). Furthermore, with beaches offering a suitable and profitable marketplace, many Senegalese chose to continue their activities as traders and street-peddlers, and they rapidly became the pioneers of Senegalese immigration in Emilia Romagna in the 1990's (Riccio and Degli Uberti, 2013).

Furthermore, besides the opportunities offered by the employment market and the implementation of new legislation, other factors also contributed to this increase in migratory flows towards Emilia Romagna, such as the activation of efficient migratory chains and local institutions' tendency to view immigration as a resource for economic development rather than a threatening phenomenon (Salih and Riccio, 2011; Marabello, 2015). According to this analytical perspective, Emilia Romagna - with its measures and policies favouring the local incorporation of migrants - runs counter to the rest of the country. Among the various Italian regional governments, in fact, only Emilia Romagna and Tuscany have modified their regional statutes to allow migrants to participate in local administrative elections.

Emilia Romagna is third among Italian regions for a number of resident foreign citizens, and it has the highest percentage of foreign residents in relation to the overall population (12\% of total residents, in 2016). There are 11,451 Ghanaians residing in Emilia Romagna, a population demographically balanced in terms of gender. Indeed, the majority have entered the country through family reunification (Marabello, 2015). Ghanaians are mostly employed as labourers in the industrial sector and small cooperative enterprises and, more recently, they have also begun to engage in autonomous entrepreneurial activities to a higher degree. Considering their tendency to stay in Italy long-term and right to hold 
double citizenship (Ghanaian and Italian), most Ghanaians in Italy have already become or are in the process of becoming new Italian citizens. From 2008 to 2015, however, the unemployment rate among migrants in Emilia Romagna quadrupled more than double the rate for autochthonous individuals. Some Ghanaians left Italy for Germany, Canada, and the United Kingdom and the current situation is uncertain.

Although numbers have recently begun to rise, in the past family reunification was not very common (Riccio, 2008) among the 10,959 Senegalese living in Italy (Osservatorio Regionale sul Fenomeno Migratorio, 2017). The situation in the 2000 s did prompt many Senegalese to prolong their stay in Italy and submit requests for family reunification, however. In contrast to the prevailing migrant profile in the 1980s and 1990s (male, single/unmarried), the practice of family reunification, which often entails the chance to settle permanently, has feminized Senegalese migration to some extent. Gasparetti and Hannaford maintain that the proportion of Senegalese women in Italy is slowly increasing, mainly as a result of family reunification (2009). From an economic viewpoint, a growing number of Senegalese who have accumulated extensive professional experience over their years in Italy are beginning to engage in autonomous entrepreneurial activities, mainly in the trade, construction, transportation and telecommunication sectors (Ceschi and Stocchiero, 2007). This scenario is changing as a result of the current economic crisis, however, as individuals coping with job loss move back and forth across regional and national borders in search of opportunities to remain in Italy or at least Europe (Marabello, 2016; Vianello, 2016).

Furthermore, it has become exceedingly difficult in recent years for African migrants to enter traditional destination countries within the European Union. The EU and its member-states have imposed further restrictions on national asylum and migration policies and have de facto outsourced border control (Gaibazzi et al., 2017). Using the pretext of national security and fear of terrorism, policy discourses and policies supported by large nationalistic segments of EU member-states' voting populations have framed and represented migrants and refugees as an unwanted economic burden and potential threat (Andersson, 2014).

This development, along with the 2008 financial crisis, has limited possibilities for a successful migration to Europe. For African migrants who are unable to beat the odds and enter Europe, life often becomes a struggle on the margins of society (Hernández-Carretero, 2016; Lucht, 2012). In this context, African migrants no longer run up against borders located solely "at the boundary" between two nation-states on a political map; such borders, they currently spring up throughout societies and national territories (Fassin, 2011). Migrants' trajectories have changed accordingly, now following less-heavily-monitored but more dangerous routes, potentially lethal paths across the desert and over the sea, often using smuggling networks to reach their destinations (Andersson, 2014). These social and economic transformations have given rise to shifting mobility strategies and driven scholars to develop new approaches to contemporary forms of mobility, bridging traditional analytical divides between internal and transnational migration, skilled and un-skilled migrations, institutional scales (international, national, regional), settlers and temporary migrants, foreigners, and autochthons, and migrant "generations". 


\section{From the "Transnational Perspective" to the "Mobile Turn"}

At the beginning of the 1990s, Nina Glick Schiller and colleagues (1992) convincingly argued that migration was not remotely a one-way process of assimilation. Instead, migrants were found to engage in multiple forms of belonging and to build social fields that cross geographical, cultural and political borders. These scholars defined transnationalism as the processes by which immigrants forge and sustain multi-stranded social relations that link up their societies of origin and settlement. Similar reflections developed in France about "territoires circulatoires" (Tarrius, 1993; Peraldi, 2002) and Italy, from a historical (Ramella, 1984), anthropological (Miranda, 1996) and sociological perspective (Ambrosini, 2008). This transnational perspective recognizes that the lives and identities of both non-migrants and migrants are linked to and affected by changing conditions of global capitalism. This approach has sought to move beyond the "methodological nationalism" that dominated social scientific ways of thinking about migration by conflating the social with the boundaries of the nation-state (Glick Schiller and Wimmer, 2002). Instead, scholars proposed a multi-scalar global approach that builds on empirical observation to explore intersecting, simultaneous and often unequal social relations across time and space, yet without overlooking the role played by the nation-state (Glick Schiller and Caglar, 2011). Indeed, transnational actions are never de-territorialized or unbounded - rather, they are bounded by the social relations and networks that migrants are part of and depend on, as well as by territorial politics and practises at both ends of the migration process (Grillo, 2018). Indeed, many empirical studies of African migration came to focus on precisely these insights into migrants' multiple social engagements and the ways in which different power structures intersect with the lives of migrants and family members (Arthur, 2008; Coe, 2011; Grillo and Mazzucato, 2008; Kane and Leedy, 2011).

In a similar vein, social sciences abound with discussions of what has been called the "mobility turn" or the "new mobilities paradigm" (Sheller and Urry, 2006) to describe a paradigm that is emerging in a wide range of social scientific disciplines, including social anthropology. To avoid treating stability as the natural state of affairs, Favell (2015) has argued that migration should constitute a "subset" of mobility studies. Indeed, as can be seen in the transnational perspective from the 1990s to the present (Vertovec, 2009), these ideas essentially stem from a criticism of sedentaristic notions of culture and society according to which cultural phenomena are treated as spatial or territorial entities. More generally, many scholars have criticized the idea that sedentarism represents normality while mobility represents deviance and therefore some kind of problem, an idea that characterised the perception of and research on migration for a long time.

From this perspective, migratory experiences cannot be conceptualised as temporally contained or strictly limited to a seemingly specific form of movement, such as linear relocation or movement between only two specific places (Cresswell, 2010). Pre-migratory experiences include various factors such as seasonal work in the region, rural-urban migration as well as engaging with individuals who migrated before, encountering stories about migratory journeys or possible destination countries (Heil et al., 2017). Many observers 
feel compelled to anchor this conceptual turn in an ethnographic foundation (Gutekunst et al., 2016; Heil et al., 2017). This kind of empirical grounding is particularly evident in the Africanist debate. Miriam de Bruijn and Rijk van Dijk, by illustrating two very different mobile groups, namely cattle herding Fulbe from Mali and Ghanaian Pentecostals, have shown how a field of practices, institutions, and ideas related to mobility has acquired dynamism in its own right (de Bruijn et al., 2001: 65). Contemporary migrants, in Europe as in Sub-Saharan Africa, act within complex systems of movement that are sometimes circular and may also integrate other linear trajectories of movements towards more extended transnational and transcontinental targets. As mentioned above, new forms of migration are similar to older ones in many ways or have been developed on the basis of those older trajectories.

In contrast to earlier transnational studies, this more comprehensive approach to mobility includes not only geographical movement in time but also social and existential mobility (see Hage, 2009). Indeed, migrants' subjectivities and movement are closely connected to imaginaries, hopes, and fantasies about social becoming and the good life (Kleist and Thorsen, 2017). By shifting the focus, scholars are able to pay attention to the mobility hierarchies, power dynamics and differentiated meanings attached to the migration process (Schapendonk and Steel, 2014). This perspective has begun to influence Italian migration studies as well. Among historians one find signs of this interest in the growing debate on internal migrations (Colucci and Gallo, 2014) as much as in the research on emigration, when Corti (2011) and later Tirabassi and Del Prà (2014 and 2016) adopted this approach to analyse "the new Italian mobility" within Europe between 2010 and 2014. There is some understandable scepticism about the way the term mobility seems to be adopted for privileged migratory experiences whereas migration is used for less privileged ones (Ambrosini, 2018); nevertheless, Vietti's ethnographic exploration ranging from the initial Albanian flows to Italy to the roots tourism of the second generation (Vietti, 2013) offers many valuable insights. More recently, research has focused on European and non-European citizens' spatial mobility within the continent where their freedom to move is used as leverage to improve their working conditions in the period of economic crisis (Sacchetto et al., 2016).

On the other hand, this debate has enlarged the notion of mobility to the extent that it is used in relation all sort of issues, sliding from traffic to tourism or forced migration as if they all constituted equivalent social phenomena. Some scholars frame mobility as a characteristic of (post-) modern human beings; it has become a virtual synonym for freedom, personal fulfilment and social fluidity or liquidity (Bauman, 1998). There is a good reason to be sceptical of readily equating mobility with freedom, however; instead, the movement should be examined not only as a connection but also as caught up with new forms of exploitation (Glick Schiller and Salazar, 2013).

Arguing that there can be no linear increase in fluidity without extensive systems of immobility, Sheller and Urry (2006) themselves have sought to analytically include both liquidity, connectivity, centrality and empowerment as well as disconnection, social exclusion, and blockages in their seminal work. The main assumption is that, especially today, the world is on the move through diverse and intersecting forms of mobility that accelerate for some while at the 
same time exacerbating immobility for others. In other words, mobility as a resource is differentially accessed. Indeed, recent socio-anthropological work has demonstrated that, for many individuals, mobility is primarily experienced in terms of its absence, as the unavailability of opportunities for departure (Gaibazzi, 2015). Immobility at home, a feeling of being stuck or the concrete inability to move (due to economic, social or political factors), may provide the initial force driving individuals to move away. For many, however, a scarcity of resources or lack of opportunity may prevent the actual move from ever taking place (Carling, 2002).

Migrants face hostile new forms of migration governance that exclude more and more people from the global circuits of legal mobility and promises of globalization (Fontanari and Pinelli, 2017). In light of this development, various migration scholars have recently argued that we need new perspectives to grasp the ways in which today's restricted border regimes curb migration and intersect with the growing migration industry and privatization of border control (Andersson, 2014; Glick Schiller and Salazar, 2013). Based on ethnographic fieldwork, other scholars challenge the assumptions mentioned above global connections and flows. Hans Lucht, for instance, problematizes the explanatory power of transnationalism for studying irregular Ghanaian migrants in Naples who struggle to get by on the margins of Italian society. Their lives are more characterized by a lack of legal and social recognition, he argues, than they are by flows and connections (Lucht, 2012).

Creswell provides the inspiring definition of mobility as "the entanglement of movement, representation, and practice" (Cresswell, 2010: 17), thereby positioning mobility in both the material world and social practices (Vammen, 2018). $\mathrm{He}$ argues that three aspects, namely physical movement, representations of movement that give rise to shared meaning, and the experience of movement, all entail particular politics of mobility: "the ways in which mobilities are both productive of such social relations and produced by them" (Cresswell, 2010: 21). This sophisticated focus allows us to combine ethnography exploring migrants' everyday lives and trajectories (see Vammen, 2018) with an investigation of the intersection between mobility, history, intergenerational tensions and the force of imagination in shaping the migration process (see Bal and Willems, 2014; Kleist and Thorsen, 2017; Salazar, 2011).

\section{From Multi-sited to Biographical Approaches to Mobility}

Multi-sited ethnography (Marcus, 1995; Coleman and Von Hellermann, 2011) and other similar ethnographic methodologies can also be adapted to movement and mobility (Salazar et al., 2017). Alternatively, researchers may address specific localities that might at first seem immobile but actually turn out to host a crossroads of various forms of mobility (as illustrated by many articles in Heil et al., 2017). In relation to migratory experiences, mobile approaches have further developed during the last years to include trajectory approaches that seek to follow open-ended migratory journeys and thus take the migratory process as their primary focus (Triulzi and McKenzie, 2013; Schapendonk and Steel, 2014; Schapendonk, 2017; Vammen, 2018). 
Migrant trajectories can be also explored through biographical tools or life histories, which often allow an in-depth analysis of experiences, changing views, sudden changes in plans, expectations, and perceptions (Bellagamba, 2012; Jourdan, 2012). All such accounts engage with repertoires of individual and collective tactics and explore how such tactics interact with the hazards, unpredictable developments and power relations shaping them. Along these lines, Camenisch and Müller (2017) call for data-based ethnographic migration research relying on the "emic perspective" of Swiss expats in China and in Sweden, research that stems from an analysis of informants' biographies. Indeed, biographies allow us to uncover diverse migratory experiences and access the deeper understanding of people's lives that emerge from them. Paying close attention to the motives and subjective experiences of mobility and the process involved in such a movement aids us in exploring how the different intersecting politics of mobility mould these particular migrant experiences. As we will show, social relations, place, and the timing of arrival significantly influence migratory experiences and trajectories as well as representations of boundaries and opportunities.

In the next section, focused on mobility in Emilia Romagna, we present migrants' accounts of their experiences at different points in time. These individual experiences are telling in that when juxtaposed, they illuminate how shifts in Italian migration governance from the 1990s onwards have altered the journeys and strategic positioning of Senegalese and Ghanaian migrants living in Emilia Romagna.

\section{C.: The Mobility Prism of Family, Social Aspirations and Hopes}

C. is a Ghanaian woman who came to Italy from Winneba, where she was working as a hairdresser. After seven years of waiting for family reunification, she finally migrated to Italy in 2005. She spent about two years in Monreale (Sicily) then moved near Bologna to join several family members including her husband, who had left the small Sicilian town the year before. Although her job as a hairdresser was informal, she described Monreale as a good place to live. Nonetheless, she was also on the lookout for new opportunities in the north of Italy together with her husband. They both represented Emilia Romagna, inhabited by a number of close family members, as a good place to work, enjoy the support of relatives and friends, and take part in larger Ghanaian communities. Just a few months after arriving in Bologna, she discovered she was pregnant. Unfortunately, her husband suffered a substantial reduction in salary due to the economic crisis and its impact on small manufacturing companies. Although this was a period of severe difficulty, C. was able to rely on the help of family members, namely her husband's oldest brother and two of her sisters, who had arrived in Bologna at almost the same time as her. Her brother-in-law, who arrived in Italy in the 1980s, obtained Italian citizenship and, after several jobs in the manufacturing sector, started a small retail company. He is very active in the local Ghanaian association and has lived for more than thirty years in Italy together with his wife, one of his sisters and two of his sons. He is the father of three sons - L., J., and P. Only one of them, the first-born L., grew up in Ghana; the other brothers were raised in Italy. After graduating, L. emigrated to the United States where he now has a white collar job; for three years, his brother J. also lived with him. 
The youngest of C.'s sisters is married to the pastor of a Pentecostal church; she has two sons and arrived in Italy after spending two years in the United Kingdom and three years in Germany. She is very proud of her role as pastor's wife and the social mobility she enjoys thanks to her husband's work. Although she lived in two countries in five years and crossed several national borders, she experienced and framed her mobility as part of her role and life in Europe as a whole, instead of focussing on the national level.

During our last interview in 2015, C. recounted developments in her family's mobility trajectories, explaining that her sister's son had applied to attend university in the United Kingdom. J., her husband's brother son who is an Italian citizen, had spent three years in the United States but, taking advantage of opportunities the Schengen treaty offers EU citizens, was attempting to move back to Europe, preferably Germany or the Netherlands. She also updated me about her experiences of navigating the economic crisis together with her husband, explaining that she had secured two informal but regularly paying jobs to supplement his salary. Considering her nephews' good prospects and professional aspirations, she was really disappointed with her eldest son, especially the fact that he was not interested in moving to the United Kingdom as she had expected. She had imagined a future for her son in London but he did not want to move outside Italy and fully intended to stay there, saying he felt at home. C. and her husband were worried about their son's future and bemoaned his lack of personal ambitions and success in life. Their son, who had spent most his life in Italy, tried to explain that he was well-established in Italy and rejected the idea of relocating to London "with Ghanaian skin colour and speaking English like an Italian...." He also added that he was happy to live near Bologna with his friends and take home his salary from a position as an events' organiser, describing it as a good job that ensured a good life, better than going to work in an English factory all day long. C. found herself quarrelling with her son frequently, making this dispute a source of concern and tension for the parents.

As part of this account, C. described kinship ties and work opportunities as deeply intertwined in younger generation Ghanaians' aspirations for social mobility. Although C. sketches mobility trajectories within and from Europe to the United States, the geographical mobility in her story - whether imagined, postponed to the future or enacted in the present - cannot be analysed as simply stemming from aspirations for and visions of a good life. The mobility or (im)mobility imagined by younger generations is embedded in their parents' migratory experiences in different countries (Italy, United Kingdom and Germany), the real opportunities offered by the contexts and social and economic conditions of arrival, and the choice of family language, English-Twi (C.'s sisters and her husband's brother in law's family) or Twi-Italian (as in the case of C.'s sons).

Other contingent factors influenced their mobility as well. Linking biographical trajectories to institutional and economic opportunities, C. brother-in-law reason for sending his oldest son back to Ghana stemmed from his first phase of migration. At the beginning of the 1980s, he arrived and waited for a sanatoria to acquire the necessary documents to go elsewhere. Eventually, however, he found a good job, enlarged his family and decided to remain in Italy where he had also bought a flat. His oldest son, L., born in that period and raised in 
Ghana, benefitted from continuous economic remittances sent by his parents from Italy, support that assured his education and successful migration to the United States.

Looking at the educational and work mobility trajectories of C.'s sons and nephews, it is clear that the individuals' various citizenship statuses, connected to state borders and legislative measures, have played a crucial role in affording them different opportunities to access mobility or allowing them to imagine moving to other countries. Hopes and aspirations for a successful life, the negative effects of the economic crisis and citizenship (Italian or European citizens) come together to forge the mobility trajectories of young people, revealing how social and geographical mobility cuts across individual and family aspirations, legal opportunities and generationally specific collective imaginaries of what constitutes a good life.

Nevertheless, the mobility recounted by $\mathrm{C}$. and her family members suggests that, although policy makers may conceive of family reunification as a means of defining a final destination, in reality, this may not be the case. Instead, family reunification may simply represent a way of gaining access to a local area and, at the same time, a temporary strategy for certain periods of life. At any rate, the mobility trajectories described here remap the usual destinations of contemporary Ghanaian diasporization (Van Hear, 1998).

\section{K.: Mobility Uncertainty}

$\mathrm{K}$. is a thirty-six year old Ghanaian man who arrived in Italy after being legally expelled from South Africa, where he had spent about eight years. In 2010, after three years living near Modena, he lost his job in a small factory. In an effort to find new employment, he worked several irregular and off-thebooks jobs, moving down the country from North to South. In southern Italy, he found a very low-paid seasonal job in agriculture. The harsh experience of agricultural work, where he was subject to a gang-master system of exploitation and daily suffering, was unexpected. In his lengthy description, K. compared this unbearable situation to slavery and emphatically told me how he struggled in that period to get in touch with friends somewhere in Europe to escape what he perceived as humiliating conditions. After some time, working through friendship contacts, he was able to move to a place near Bologna where he secured a modest new job and was supported by local voluntary associations to obtain a special residence-permit as a victim of employment slavery. The local context, with its substantial associations working for workers' rights, supported K. in re-shaping his harsh exploitation experience as a means of gaining access to Italian soil as a regular migrant and worker.

Sites of past migration and future imagined destinations chase each other through the interview. K., relying on the narratives of contacts and friends, outlined his idea of migrating to places such as China or Dubai, considering them good places to find a job. At the same time, however, he admitted that the geographical distance and his limited economic resources were, at that moment, an insurmountable obstacle to such plans. Instead, considering its geographical proximity and the documents he was able to obtain, he was planning to join some friends in Germany in a few months' time with the idea of finally pursuing 
a successful life. K.'s account illustrates how uncertainty and unpredictable elements orient the trajectories of migrants who move through historical (for instance, South Africa as a goal for Ghanaian migrants) and more recent destinations (Italy, since the 1980s). Social imaginaries and collective representations of localities contribute to informing and re-orienting individual plans. And, lastly, K.'s brief biographical snapshot aids us in recognizing how regular/irregular migration and voluntary/forced migration tend to overlap and become stratified. Nevertheless, the two types of legal permits granting him worker status, once irregular and then newly entitled to stay in the country with a special permit for victims of labour abuse, show that regular/irregular (Ambrosini, 2018; Cvajner and Sciortino, 2011) are also embedded in the national legal framework in question. Furthermore, at the theoretical level, this ethnographic account challenges the heuristic value of rigid categorisations such as "labour migrant" or "victim seeking protection". A lack of either economic resources or strong social networks prevents $\mathrm{K}$. from reaching the imagined mobility destinations that serve as landmarks in his movements from one temporary spatial goal to the next with the idea, emphasised in his narrative, of finally achieving a secure and successful life in the future. Moreover, K.'s story illustrates how people experience mobility and enclosures involving unequal rights and power (Cunningham and Heyman, 2004). Taking into account the enclosures that restrict specific people and linking them to mobility as an analytical tool can help us to connect up processes and trajectories along time/space by examining how structural, legal and economic constraints orient people's ideas and ability to navigate life's unexpected events.

\section{B.: A Privileged Pivotal Player of Mobility}

Taking power dynamics into account, a mobilities-informed ethnography (Camenisch and Müller, 2017) may help in overcoming what Hui has called "migrant exceptionalism" (2016). It challenges the scientific construction of "the migrant" as a unique subject through the study of "sometimes-migrants." In contrast to the migrant exceptionalism that prevails in migration studies, mobility studies shed light on "all those who travelled within a country or circled the globe" (Glick Schiller and Salazar, 2013: 183-184). Furthermore, a mobility perspective makes it easier for scholars to include privileged migratory experiences in the field of migration studies, a field more accustomed to focusing on less privileged forms of migration (Smith and Favell, 2006; Ambrosini, 2018). B., a Senegalese woman with an extensive educational background, speaks multiple languages and has held a variety of professional positions. She often acts as a "cultural and linguistic mediator" in various institutional settings (Institutional accommodations for migrants, hospitals and other health centres, migrant detention and processing centres, etc.) and through collaboration with different kinds of associations. She arrived in Italy at the end of the 1990s and ten years later, besides being very active in the longstanding Senegalese Association of Ravenna, she founded and presided over an association of Senegalese women focused on facilitating professional training for its members (seven out of twenty found jobs in the service sector, such as cleaning or restaurant work) and opening the first Senegalese restaurant in Ravenna.

In other words, she made a career of navigating the institutional complex that grew up in the wake of local regional policies governing migrants and their 
children. As mentioned above, Emilia-Romagna is often considered to be one of Italy's most progressive regions in terms of migrant social policies. Throughout the 1990s and until the second half of the 2000s, such local policies accompanied migrants as they settled throughout the region, including measures to foster "integration" through reception centers, health centers, housing, professional training, cultural initiatives, support for migrant associations and education. All of these fields employed linguistic and cultural brokerage, and it was here that B. developed her professional expertise.

More recently, she also decided to engage in local public space by helping to organize campaigns promoting citizenship law reform and raising awareness among Italian institutional and educational actors about the problems faced by young Italians from a migrant background (see Miranda, 2012; Riccio, 2012). Citizenship is an important tool of inclusion, endowing migrants and their children with rights equal to their peers. More restrictive laws on citizenship fuel racism and exclusion. The 1992 Italian citizenship law made it easier for descendants of Italian emigrants to regain citizenship but also much more difficult for migrants to apply for naturalization and more restrictive with regard to the second generation. Indeed, it requires Italian-born children of foreign parents to assume their parents' nationality and does not allow them to request Italian citizenship until they are eighteen years old and even then only if they have continually resided in Italy. As a result, the children of migrants born in Italy are not automatically granted Italian citizenship; they have to apply for it and wade through a complicated bureaucratic process. The most precarious condition, however, is that of young people who came to Italy when they were children or young adolescents only to discover that they were "foreigners" when they reached adulthood. Many associations representing the second generation have sprung up recently to reform these restrictive citizenship laws.

Indeed, this is one of the main goals of IGOF (Italians Generation of Foreign Origin), a small, ethnically mixed association in Ravenna. When this idea was proposed within the broader Senegalese association, however, some members reacted with a certain degree of suspicion. One representative of the Senegalese embassy who happened to be present questioned the value of Italian citizenship when "the ultimate Senegalese goal is the return to and well-being of Senegal". At the same time, others counter-argued that the future of children in Italy depends on changing this law and that the future prospects of migrants who have been in Italy since the end of the 1980's would benefit from it as well. "There were members shouting that they were sick and tired of going through the blackmail and bureaucratic nightmare of renewing their permits to stay and would rather be Italian citizens". Obviously, most of the Senegalese interested in this campaign belonged to the minority who had undergone family reunification and wanted to ensure a better future for their children in Italian society: "they were born in Italy, they have studied here and they want their belonging to Italian society be recognized on paper as much as in their daily life".

The association's public goals include objectives such as bringing the Italian citizenship law around to jus solii while also preserving the languages and cultures of their contexts of origin. The "bifocal" (Vertovec, 2009) focus of the association is evidenced by the fact that one of the first projects they developed in collaboration with the local branch of Italy's most important trade union 
(CGIL) involved supporting older migrants in their efforts to make a respectable return to Senegal. Most of them, after having held different professional positions (enterprises, cooperatives, self-employment, employee, etc.) are now facing bureaucratic difficulties in renewing their permits to stay, even as their savings have been dramatically diminished with the economic crisis. The project entailed facilitating a "dignified return" through programs potentially involving local government, associations, NGOs and trade unions. Each component (the returning migrant her or himself, the nation-state, regional and local government) would provide one-fifth of the overall budget for implementing the project (see Ceschi, 2012). The remaining eighth of the budget would be covered by the association or other organizations (NGOs, trade unions) involved.

Senegalese migrants retain a strong attachment to their country of origin, maintaining significant ties, supporting their families, sending remittances, investing and, ultimately, preparing the terrain for a future return. Many studies show that Senegalese migrants see their country of origin as home, a source of identification and the place they ultimately yearn to return to (Riccio, 2006; Kane, 2011). However, as Sinatti (2011) has shown, although return seems to be the goal of many Senegalese migrants, they struggle to accumulate the resources needed to resettle in the home country. Co-development projects aimed at ensuring a suitable return often fail due to a lack of economic solidity and the contemporary effects of migration. Families frequently become dependent on remittances, and remaining in a state of migration may appear to be the only feasible solution for meeting their expectations. Furthermore, "remittances and the social and economic promotion enjoyed by the family left behind, as a result, become a reward that compensates for the [migrant's] lack of constant physical presence in the household" (Sinatti, 2011: 160).

Therefore, the prospect of forever remaining "transmigrants" (Riccio, 2006; Grillo, 2018) often appears more realistic than that of an ultimate return. As suggested above, the tendency to circulate, alternating return and re-emigration, appears of greater interest than practices of a permanent return. On the other hand, there is a generation of older migrants who came to Italy in the 1980s and are now encountering problems associated with residing in Italy, such as the denial of applications to renew their residence permits. They find themselves unable to organize a proper final return to Senegal, a dignified return that would earn them the proper recognition. It is these individuals, bound to return, who are the targets of the project mentioned above. This example illustrates a form of intergenerational solidarity that calls into question the on-going American sociological debate on assimilation vs transnationalism (Riccio and Degli Uberti, 2013).

Today, the members of second-generation Senegalese associations who are politically engaged in addressing the highly contested issue of citizenship appear to be at the forefront of active participation and dual engagement. Although the public agendas of groups such as IGOF are focused on combatting discrimination and overcoming barriers to social mobility and full citizenship rights, these objectives are accompanied by efforts to preserve native languages and cultivate connections with the context of origin. The story of B. suggests a more complex and articulated state of affairs. Migrants' cosmopolitan forms of organization and serious efforts to ensure the future of the children of Italian immigration by 
securing citizenship rights for the second generation are compatible with civic participation in the context of origin and relations of solidarity among different migration stages and generations, a fact which runs counter to both prevailing academic discourses and common sense assumptions.

The three briefly sketched biographies allow us to explore the politics of mobility (Cresswell, 2010) by observing how different trajectories and narratives depend on temporal phases of arrival as well as institutional and social opportunities. The highly resourceful Senegalese woman helping to shape what Simone (2004) has defined as the "human infrastructure" of mobility connecting generations of migrants as well as context of migrations shows how personal abilities but also place, employment opportunities and time of arrival (the 1990s) interact to produce, assert, and frame ideas about mobility. K.'s arrival in the 2000s helps us grasp how "mobility regimes" (Glick Schiller and Salazar, 2013) are experienced by individual migrants who attempt to overcome legal and economic restraints by navigating Italy's internal gaps and opportunities. K. arrived in Italy via a brother who moved back to Ghana and, lacking a strong social net or reasonably good salary, moved up and down across internal Italian borders attempting to use mobility as a strategy for overcoming uncertainty. Although C. arrived in Italy in the same period (the 2000s), she had a different experience. Looking through the lens of her biography, we can glimpse mobility trajectories spanning different subjects and generations and crossing national and international borders, thereby grasping how legal status, time and condition of arrival as well as individual aspirations intersect. These factors come together to mould concrete and/or imagined spaces of mobility. The three biographies presented here shed light on the regional context of Emilia Romagna, characterised by a social dynamic of change and migrant inclusion, an energetic economy and, compared with the national view on migration, a fairly long-sighted approach (Salih and Riccio, 2011).

\section{Conclusion}

By combining the history of West African migration to Italy from the 1980s to the present with contemporary theoretical approaches to migration and the biographical exploration of several cases, we argue that mobility seems to offer an effective research perspective for contemporary social anthropology.

Aiming to observe changes in Italy's socio-political landscape, we first highlighted the link between migration laws and migratory trends, suggesting four stages of settlement. The two initial phases were closely linked to the implementation of the governmental laws (sanatoria) issued in 1986 and 1989 to regularize the status of migrants. The third phase began during the 1990s when Italian participation in the Schengen treaty and the development of more comprehensive, albeit stratified and increasingly restrictive laws, shifted migration dynamics. Nationality, gender, and education level affected migrants' access to Italian labour markets and regional territories. Beginning at the end of the 1990s, the current, fourth stage has been characterised by more restrictive laws as well as new border control policies and the impact of the recent economic crisis. Focusing on Emilia Romagna as a migration destination, we explored Ghanaian and Senegalese migration from the end of the 1980 s to the present, 
observing how legal frames, labour reduction and economic development such as the 2008 economic financial crisis impacted migrants' plans, routes, and daily lives. Several of these factors stimulated internal migration within Italy as well as new migratory perspectives for the younger generations. Based on the long-term research of both authors, we juxtaposed interview materials to explore migrants' representations, narratives and geographical movements in time but also social and existential mobility (see Hage, 2009). By paying attention to temporal and spatial dimensions in our sketches of three biographies of Ghanaian and Senegalese migrants, we have attempted to show how a mobility-informed ethnography sheds light on plans, representations, and tactics used by migrants in navigating economic, legal, and political constraints. Both of the Ghanaian stories help reveal how, despite social aspirations, people's trajectories and projects are embedded within specific economic and political processes that restrict or allow individual instances of migration (Cunningham and Heyman, 2004). Moreover, the two Ghanaian biographical accounts help the reader see how borders - very often insurmountable - are imagined, mapped, and crossed as well as the way individuals experience legal frames and rights. In contrast, the Senegalese woman's biography aids us in grasping how a cosmopolitan vision and dual engagement in the contexts of origin and destination can contribute to creating the social conditions for mobility across different generations (see Cingolani, 2017).

Lastly, these brief ethnographic accounts demonstrate how legal conditions of access powerfully influence the migration journeys and positioning of Senegalese and Ghanaian migrants living in Emilia Romagna and how the local context contributes to shaping their participation or new (imagined) migration routes and goals. The biographical perspective allows us to observe migrants' movements, imaginaries and hopes about social becoming and the good life in order to understand how individual, family, and social repertoires engage with hazards and power relations (Kleist and Thorsen, 2017). Inspired by Cresswell (2010), we have outlined the theoretical debate to show how a politics of mobility centred on the material and social practices embodied by migrants makes it possible to conduct an ethnography of migrants' everyday lives that is attentive to the entanglement of mobility, history and intergenerational tensions. By illustrating how biographical experiences interact with sending/receiving countries, legal and economics restraints, hopes and aspirations, this study presents mobility as an effective tool for analysing the borders underlying tensions and re-configuration in contemporary migration processes. 


\section{References}

Ambrosini Maurizio (2018) Irregular Immigration in Southern Europe. Actors, Dynamics and Governance, Basingstoke, Palgrave McMillan, 164 p.

Ambrosini Maurizio (2017) Migrazioni, Milano, Egea, 162 p.

Ambrosini Maurizio (2008) Un'altra globalizzazione. La sfida delle migrazioni transnazionali, Bologna, II Mulino, $247 \mathrm{p}$.

Andersson Ruben (2014) Illegality Inc. Clandestine Migration and the Business of Bordering Europe, Berkeley, University of California Press, 360 p.

Arthur John (2008) The African Diaspora in the United States and Europe. The Ghanaian Experience, Aldershot, Ashgate, $210 \mathrm{p}$.

Augé Marc (2012) Pour une anthropologie de la mobilité, Paris, Payot \& Rivages, $107 \mathrm{p}$.

Bal Ellen and Willems Roos (2014) Aspiring migrants, local crisis and the imagination of futures "away from home", Identities: Global Studies in Culture and Power, 21 (3), pp. 249-258.

Bauman Zygmunt (1998) Globalization. The Human Consequences, Cambridge, Polity, $136 \mathrm{p}$.

Bellagamba Alice (2012) Passando per Milano. Kebba Suwareh, immigrato dal Gambia, e le conseguenze dell'illegalità, Antropologia, 13 (15), pp. 21-38.

Camenisch Aldina and Muller Seraina (2017) From (E)Migration to Mobile Lifestyles: Ethnographic and Conceptual Reflections about Mobilities and Migration, New Diversities, 19 (3), pp. 43-57.

Carling Jørgen (2002) Migration in the Age of Involuntary Immobility:Theoretical Reflections and Cape Verdean Experiences, Journal of Ethnic and Migration Studies, 18 (1), pp. 5-42.

Ceschi Sebastiano (Ed.) (2012) Movimenti migratori e percorsi di cooperazione. L'esperienza di co sviluppo di Fondazioni4Africa-Senegal, Roma, Carocci, 198 p.

Ceschi Sebastiano et Stocchiero Andrea (Éds.) (2007) Relations transnationales et co-développement. Associations et entrepreneurs sénégalais entre Italie et lieux d'origine, Paris, L'Harmattan, $272 \mathrm{p}$.

Cingolani Pietro (2017) Transitions to Adulthood in Romania: A Diachronic and Intergenerational Approach to Mobility Regimes, New Diversities, 19 (3), pp. 59-74.

Coe Cathy (2011) What is the impact of transnational migration on family life? Women's comparison of internal and international migration in a small town in Ghana, American Ethnologist, 38 (1), pp. 148-63.

Coleman Simon and Von Hellermann Pauline (Eds.) (2011) Multisited Ethnography. Problems and Possibilities in the Translocation of Research Methods, London, Routledge, $220 \mathrm{p}$.

Colombo Asher (2012) Fuori controllo? Miti e realtà dell'immigrazione in Italia, Bologna, II Mulino, 202 p.

Colucci Michele e Gallo Stefano (Eds.) (2015) Tempo di cambiare, Rapporto 2015 sulle migrazioni interne in Italia, Roma, Donzelli, $172 \mathrm{p}$. 
Corti Paola (2011) La nuova mobilità degli italiani e le migrazioni internazionali, in Adelina Miranda e Amalia Signorelli Eds., Pensare e ripensare le migrazioni, Palermo, Sellerio, pp. 120-134.

Cresswell Tim (2010) Towards a politics of mobility, Environment and Planning D, Society and Space, 28 (1), pp. 17-31.

Cunningham Hilary and Heyman Josiah (2004) Introduction: Mobilities and Enclosures at Borders, Identities: Global Studies in Culture and Power, 11 (3), pp. 289-302.

Cvajner Martina and Sciortino Giuseppe (2011) Theorizing Irregular Migration: The Control of Spatial Mobility in Differentiated Societies, European Journal of Social Theory, 13 (3), pp. 389-404.

De Bruijn Mirjam, Van Dijk Rijk and Foeken Dick (Eds.) (2001) Mobile Africa. Changing Patterns of Movement in Africa and Beyond, Leiden, Brill, 230 p.

Degli Uberti Stefano (2014) Victims of their Fantasies or Heroes for a Day? Media Representations, Local History and Daily Narratives on Boat Migrations from Senegal, Cahiers d'Études Africaines, 1 (213-214), pp. 81-113.

Fassin Didier (2011) Policing Borders, Producing Boundaries. The Governmentality of Immigration in DarkTimes, Annual Review of Anthropology, 40, pp. 213-226.

Favell Adrian (2015) Rebooting migration theory: Interdisciplinarity, Globality and Postdisciplinarity in Migration Studies, in Caroline Brettell and James Hollifield Eds., Migration Theory: Talking Across Disciplines, NewYork, Routledge, pp. 259-278.

Fontanari Elena and Pinelli Barbara (Eds.) (2017) Refugees experiences in Europe. Subjectivity, surveillance and control, Etnografia e Ricerca Qualitativa, $10(1), 155 \mathrm{p}$.

Gaibazzi Paolo (2015) Bush Bound. Young Men and Rural permanence in Migrant West Africa, Oxford, Berghahn, 218 p.

Gaibazzi Paolo, Dünnwald Stephan and Bellagamba Alice (Eds.) (2017) Eurafrican borders and migration management: Political cultures, contested spaces and ordinary lives, New York, Palgrave Macmillan, 302 p.

Gasparetti Fedora (2011) Relying on Teranga: Senegalese Migrants to Italy and their Children Left Behind, Autrepart, 1 (57-58), pp. 215-232.

Gasparetti Fedora and Hannaford Dinah (2009) Genitorialità a distanza: reciprocità e migrazione senegalese, Mondi Migranti, 1, pp. 111-131.

Glick-Schiller Nina and Caglar Ayse (Eds.) (2011) Locating Migration. Rescaling Cities and Migrants, Ithaca, Cornell University Press, 296 p.

Glick-Schiller Nina and Salazar Noel (2013) Regimes of Mobility across the Globe, Journal of Ethnic and Migration Studies, 39 (2), pp. 183-200.

Glick-Schiller Nina and Wimmer Andreas (2002) Methodological Nationalism and Beyond: Nation-State Building, Migration and the Social Sciences, Global Networks, 2 (4), pp. 301-334.

Grillo Ralph David (2018) Transnational Migration and Multiculturalism. Living with Difference in a Globalised World, Lewes, B \& RG Books, 486 p. 
Grillo Ralph David and Mazzucato Valentina (2008) Africa/Europe: A Double Engagement, Journal of Ethnic and Migration Studies, 2 (34), pp. 175-198.

Grillo Ralph David and Pratt Jeff (Eds.) (2002) The Politics of Recognizing Difference: Multiculturalism Italian-Style, Aldershot, Ashgate, 286 p.

Gutenkust Miriam, Hackl Andreas, Leoncini Sabina, Schwartz Julia Sophia and Gotz Irene (Eds.) (2016) Bounded Mobilities. Ethnographic Perspectives on Social Hierarchies and Global Inequalities, Bielefeld, Transcript, 296 p.

Hage Ghassan (2009) Waiting, Melbourne, Melbourne University Press, 256 p.

HeilTilmann, Priori Andrea, Riccio Bruno and Schwarz Inga (Eds.) (2017) Mobilities. Migratory Experiences Ethnographically Connected, New Diversities, 19 (3), 87 p.

Hernandez-Carretero María (2016) Leaving to belong: migration, transnational connectedness and social becoming, PhD Thesis, Faculty of Social Sciences, University of Oslo, 202 p.

Hui Allison (2016) The Boundaries of Interdisciplinary Fields: Temporalities Shaping the Past and Future of Dialogue between Migration and Mobilities Research, Mobilities, 11 (1), pp. 66-82.

Jourdan Luca (2012) Sono I'uomo giusto nel posto e momento sbagliato. Storia di un rifugiato eritreo a Kampala (Úganda), Antropologia, 14, pp. 259-275.

Kane Abdoulaye and Leedy Todd (Eds.) (2011) African Migrations. Patterns and Perspectives, Bloomington, Indiana University Press, 316 p.

Kane Ousmane (2011) The Homeland is the Arena: Religion, Transnationalism, and the Integration of Senegalese Immigrants in America, New York, Oxford University Press, $313 \mathrm{p}$.

Kleist Nauja (2017) Introduction, in Nauja Kleist and Dorte Thorsen Eds., Hope and Uncertainty in Contemporary African Migration, London, Routledge, 200 p.

Kleist Nauja and Thorsen Dorte (Eds.) (2017) Hope and Uncertainty in Contemporary African Migration, London, Routledge, 200 p.

Lucht Hans (2012) Darkness Before Daybreak: African Migrants Living on the Margins in Southern Italy Today, Berkeley, University of California Press, 306 p.

Manchuelle François (1997) Willing Migrants: Soninke Labor Diasporas, 18481960, Athens, OH, Ohio University Press, 371 p.

Manuh Takyiwaa (2006) An 11 th Region of Ghana? Ghanaians Abroad, Accra, Ghana Academy of Arts and Sciences, 105 p.

Marabello Selenia (2016) Internal and International Migrants Navigate Italy's South-North Border, in Bruno Riccio Ed., From Internal toTransnational Mobilities, Bologna, Odoya, pp. 177-192.

Marabello Selenia (2015) Ghanaian Migrants to Italy as Agents of Change? Making sense of gender hierarchies and development discourses, L'Uomo, 1, pp. 22-53.

Marcus George (1995) Ethnography in/of the World System. The Emergence of Multi-Sited Ethnography, Annual Review of Anthropology, 24, pp. 95-97.

Miranda Adelina (Éd.) (2012) Être étranger chez soi : les jeunes d'origine immigrée en Italie, Migrations Société, 24, pp. 141-142. 
Miranda Adelina (1996) Migrants et non-migrants d'une communauté italienne, Paris, L'Harmattan, $188 \mathrm{p}$.

Nieswand Boris (2011) Theorising Transnational Migration. The Status Paradox of Migration, London, Routledge, 212 p.

Osservatorio Regionale sul Fenomeno Migratorio (Ed.) (2017) L'immigrazione straniera in Emilia-Romagna, Regione Emilia Romagna, [online] last checked on 08/02/2017. URL: https://assr.regione.emilia-romagna.it/it/servizi/pubblicazioni/ rapporti-documenti/immigrazione-straniera-ER-rapporto-2017

Peraldi Michel (Éd.) (2002) La fin des norias: Réseaux migrants dans les économies marchandes en Méditerranée, Paris, Éditions Maisonneuve, 495 p.

Pugliese Enrico (2006) L'Italia tra migrazioni internazionali e migrazioni interne, Bologna, II Mulino, $192 \mathrm{p}$.

Ramella Francesco (1984) Terra e telai: sistemi di parentela e manifattura nel Biellese dell'Ottocento, Torino, Einaudi, 280 p.

Riccio Bruno (Ed.) (2016) From Internal to Transnational Mobilities, Bologna, Odoya, $208 \mathrm{p}$.

Riccio Bruno (2012) Citoyenneté, représentations et discriminations: les associations des jeunes d'origine étrangère à Bologne, Migrations Société, 24, pp. 141-142.

Riccio Bruno (2008) West African Transnationalisms Compared: Ghanaians and Senegalese in Italy, Journal of Ethnic and Migration Studies, 34 (2), pp. 217-234.

Riccio Bruno (2006) "Transmigrants " mais pas " nomades »: Transantionalisme mouride en Italie, Cahiers d'Études Africaines, 181, pp. 95-114.

Riccio Bruno and Degli Uberti Stefano (2013) Senegalese Migrants in Italy: Beyond the Assimilation/Transnationalism Divide, Urban Anthropology, 42, pp. 207-254.

Sacchetto Devi, Vianello Francesca Alice and Andrijasevic Rutvica (2016) Le migrazioni lavorative intra-UE: modelli, pratiche e traiettorie di mobilità dei cittadini europei, Mondi Migranti, 3, pp. 23-31.

Salazar Noel (2011) The Power of Imagination in Transnational Mobilities, Identities, Global Studies in Culture and Power, 18 (6), pp. 576-598.

Salazar Noel, Elliot Alice and Norum Roger (2017) Studying MobilitiesTheoretical Notes and Methodological Queries in Noel Salazar, Alice Elliot and Roger Norum Eds., Methodologies of Mobility. Ethnography and Experiment, Oxford, Berghahn, $216 \mathrm{p}$.

Salih Ruba and Riccio Bruno (2011). Transnational Migration and Rescaling Processes: The Incorporation of Migrant Labor, in Nina Glick Schiller and Ayse Caglar Eds., Locating Migration: Rescaling Cities and Migrants, Ithaca, Cornell University Press, pp. 123-142.

Schapendonk Joris (2017) Afrostars and Eurospaces West African movers re-viewing "Destination Europe" from the inside, Etnografia e Ricerca Qualitativa, 3, pp. 393-413.

Schapendonk Joris and Steel Griet (2014) Following Migrant Trajectories:The Im/ Mobility of Sub-Saharan Africans en Route to the European Union, Annals of the Association of American Geographers, 104 (2), pp. 262-270. 
Schuster Liza (2005) The Continuing Mobility of Migrants in Italy: Shifting between Places and Statuses, Journal of Ethnic and Migration Studies, 31 (4), pp. 757-774.

Sheller Mimi and Urry John (2006) The New Mobilities Paradigm, Environment and Planning, 38, pp. 207-226.

Simone AbdouMaliq (2004) People as Infrastructure: Intersecting Fragments in Johannesburg, Public Culture, 16 (3), pp. 407-429.

Sinatti Giulia (2011) Mobile Transmigrants or Unsettled Returnees? Myth of Return and Permanent Resettlement among Senegalese Migrants, Population, Space and Place, 17 (2), pp. 153-166.

Smith Michael Peter and Favell Adrian (Eds.) (2006) The Human Face of Global Mobility, New Brunswick, Transaction Publishers, $314 \mathrm{p}$.

Tarrius Alain (1993) Territoires circulatoires et espaces urbains. Différentiation des groupes migrants, Les Annales de la recherche urbaine, 59-60, pp. 51-60.

Timera Mahamet (1996) Les Soninké en France. D'une histoire à l'autre, Paris, Karthala, $244 \mathrm{p}$.

Tirabassi Maddalena and Del Prà Alvise (2016) The new Italian mobility in Europe, in Bruno Riccio Ed., From Internal to Transnational Mobilities, Bologna, Odoya, pp. 111-136.

Tirabassi Maddalena e Del Prà Alvise (2014) La meglio Italia. Le mobilità italiane nel XXI secolo, Turin, Accademia University Press, 240 p.

Triulzi Alessandro and McKenzie Robert (Eds.) (2013) Long Journeys. African Migrants on the Road, Leiden, Brill, 266 p.

Vammen Savio Ida Marie (2018) The Madness of Migration. An Ethnographic Account of Senegalese Migrants' Mobility and Lives in Buenos Aires, PhDThesis, Faculty of Social Sciences, University of Copenhagen, 303 p.

Van Hear Nicholas (1998) New Diasporas: The Mass Exodus, Dispersal and Regrouping of Migrant Communities, London, UCL Press, $316 \mathrm{p}$.

Vertovec Steven (2009) Transnationalism, London, Routledge, 205 p.

Vianello Francesca (2016) Landscapes of Mobility of EU and non EU Migrants Living in Italy. A Layering of Internal Movements, in Bruno Riccio Ed., From Internal to Transnational Mobilities, Bologna, Odoya, pp. 155-176.

Vietti Francesco (2013) Hotel Albania. Viaggi, migrazioni, turismo, Roma, Carocci, 193 p. 


\section{Selenia Marabello and Bruno Riccio}

\section{West African Migrations to Italy: An Anthropological Analysis of Ghanaian and Senegalese Politics of Mobility in Emilia Romagna}

In this article we combine a mobility perspective with a biographical approach to explore the Italian experience of Ghanaian and Senegalese migration emphasising expectations, obstacles and practices in contexts of uncertainty and precariousness. First, we provide readers with an historical background of West African migration to Italy, and Emilia Romagna in particular, from the end of the 1980s to the present. We highlight the link between migration laws and migratory trends. We then theoretically engage with the mobility paradigm and its impact on the socio-anthropological study of migration. Finally, we analyse biographical trajectories looking at the interplay between migrants' life strategies and shifting normative and economic structures. We conclude by arguing that mobility seems to offer an effective research perspective for contemporary social anthropology by shedding light on plans, representations and tactics used by migrants in navigating economic and political constraints.

\section{Migrations ouest-africaines vers I'Italie : une analyse anthropologique des politiques de mobilités ghanéennes et sénégalaises en Émilie-Romagne}

Dans cet article, nous combinons une perspective de mobilité avec une approche biographique pour explorer l'expérience italienne de la migration des Ghanéens et des Sénégalais en soulignant les attentes, les obstacles et les pratiques qui les attendent dans un contexte d'incertitude et de précarité. Pour commencer, nous rappelons le contexte historique de la migration ouest-africaine en Italie, et plus particulièrement celui de l'Émilie-Romagne, de la fin des années 1980 à nos jours. Nous soulignons le lien entre les lois sur l'immigration et les tendances migratoires. Nous nous intéressons ensuite au paradigme de la mobilité pour évaluer son impact sur l'étude socio-anthropologique de la migration. Et pour finir, nous analysons les trajectoires biographiques des migrants en soulignant l'interaction entre les stratégies de vies des migrants et l'évolution des normes et des structures économiques. Nous concluons en affirmant que le paradigme de la mobilité semble offrir une perspective de recherche pertinente pour l'anthropologie sociale, permettant d'éclairer les plans, les représentations et les tactiques des migrants, dans leur gestion des contraintes économiques et politiques. 


\section{Las migraciones de África Occidental a Italia: un análisis antropológico de las políticas de movilidad desde Ghana y Senegal en Emilia Romagna}

En este artículo se explora, a través de la perspectiva de la movilidad y un enfoque biográfico, la experiencia italiana de la migración desde Ghana y Senegal, haciendo hincapié en las expectativas, los obstáculos y las prácticas en contextos de incertidumbre e inestabilidad. Se proporciona a los lectores un trasfondo histórico de la migración de África occidental a Italia, y Emilia Romagna en particular, destacando la relación entre las leyes de migración y las tendencias migratorias. A continuación, analizamos las trayectorias biográficas observando la interacción entre las estrategias de vida de los migrantes y las cambiantes estructuras normativas y económicas. Concluimos argumentando que el paradigma de la movilidad parece ofrecer una perspectiva de investigación efectiva para la antropología social contemporánea al arrojar luz sobre los planes, las representaciones y las tácticas utilizadas por los migrantes para sortear las restricciones económicas y políticas. 